\title{
Differential livelihood adaptation to social-ecological change in coastal Bangladesh
}

\author{
Sonia Ferdous Hoque ${ }^{1}$ - Claire Quinn ${ }^{1} \cdot$ Susannah Sallu $^{1}$
}

Received: 14 December 2015 / Accepted: 3 August 2017 / Published online: 18 August 2017

(C) The Author(s) 2017. This article is an open access publication

\begin{abstract}
Social-ecological changes, brought about by the rapid growth of the aquaculture industry and the increased occurrence of climatic stressors, have significantly affected the livelihoods of coastal communities in Asian mega-deltas. This paper explores the livelihood adaptation responses of households of different wealth classes, the heterogeneous adaptation opportunities, barriers and limits (OBLs) faced by these households and the dynamic ways in which these factors interact to enhance or impede adaptive capacities. A mixed methods approach was used to collect empirical evidence from two villages in coastal Bangladesh. Findings reveal that households' adaptive capacities largely depend on their wealth status, which not only determine their availability of productive resources, but also empower them to navigate social-ecological change in desirable ways. Households operate within a shared response space, which is shaped by the broader socio-economic and political landscape, as well as their previous decisions that can lock them in to particular pathways. While an adaptive response may be effective for
\end{abstract}

Editor:Marc J. Metzger

Electronic supplementary material The online version of this article (doi:10.1007/s10113-017-1213-6) contains supplementary material, which is available to authorized users.

Sonia Ferdous Hoque

soniahoque@gmail.com

Claire Quinn

c.h.quinn@leeds.ac.uk

Susannah Sallu

s.sallu@leeds.ac.uk

1 Sustainability Research Institute, School of Earth and Environment, University of Leeds, Leeds, UK one social group, it may cause negative externalities that can undermine the adaptation options and outcomes of another group. Adaptation OBLs interact in complex ways; the extent to which these OBLs affect different households depend on the specific livelihood activities being considered and the differential values and interests they hold. To ensure more equitable and environmentally sustainable livelihoods in future, policies and programs should aim to expand households' adaptation space by accounting for the heterogeneous needs and complex interdependencies between response processes of different groups.

Keywords Livelihood trajectories · Shrimp aquaculture · Divergent adaptation $\cdot$ Opportunities and barriers

\section{Introduction}

Coastal communities in Asian mega-deltas have experienced significant social-ecological changes in the past few decades, particularly due to the rapid growth of the aquaculture industry and increased occurrence of natural shocks and stresses (Abdullah et al. 2016; Orchard et al. 2016). Households' capacities to adapt their livelihoods to these changes are shaped by a number of factors at multiple scales, which can act individually or together to impede the planning, implementation or effectiveness of adaptation strategies (Shackleton et al. 2015). While these factors have been implicitly recognised in adaptation studies over a long time, 'barriers' and 'limits' to adaptation have received specific focus in the academic literature in recent years (Antwi-Agyei et al. 2015; Klein et al. 2014). Some of the commonly reported barriers are bio-physical or natural (Sallu et al. 2010), socio-cultural (Curry et al. 2015; Jones and Boyd 2011), financial or economic (Bryan et al. 2009; Deressa et al. 2009), technological 
(Islam et al. 2014), institutional (Quinn et al. 2011) and psychological (Gifford 2011; Grothmann and Patt 2005). However, studies in this genre have generally considered barriers as having a uniform adverse effect on all actors, largely overlooking the particular nature and impact of such barriers on different actors (Mersha and Van Laerhoven 2016). There is a greater need to study the diverse influences of barriers on different social groups, stratified by wealth status, gender, ethnicity or other demographic factors. Power imbalances and conflicts in interests among social actors are likely to influence the processes and outcomes of social-ecological change, thus, creating winners and losers (Ingalls and Stedman 2016). As such, it is necessary to understand the trade-offs involved, particularly identifying the impacts of adaptation strategies undertaken by one group on the adaptive capacity of another (Shackleton et al. 2015).

In this paper, we aim to provide an empirical analysis of heterogeneous adaptation opportunities, barriers and limits (referred to as OBLs, henceforth) faced by households of different wealth classes and present the dynamic ways in which these factors interact to enhance or impede adaptive capacities. In doing so, we draw on empirical evidence from southwestern coastal Bangladesh - an active deltaic floodplain located on the lower reaches of the Ganges-BrahmaputraMeghna (GBM) catchment (Abdullah et al. 2016; Huq et al. 2015). The region is highly susceptible to tropical cyclones and tidal surges, particularly in the pre-monsoon and postmonsoon periods. Intrusion of saline water from the Bay of Bengal poses significant challenges in the dry season when lack of rainfall decrease upstream river flows. This seasonal phenomenon has been exacerbated by the withdrawal of water at the Farakka dam in India and the construction of hundreds of coastal 'polders' (embanked islands) in Bangladesh during the 1960s-70s (Islam and Gnauck 2008). Construction of these polders was part of the 'green revolution' that sought to intensify crop production and increase food security by protecting agricultural land from tidal floods and salinity intrusion (Islam and Kibria 2006).

Since the late 1970s, these polders also facilitated the growth of the aquaculture industry - the two main species being the brackish water Bagda shrimp (Penaeus monodon) and freshwater Galda prawn (Macrobrachium rosenbergii). This 'blue revolution' was not unique to Bangladesh; export oriented aquaculture transitions were promoted in poor indebted countries by international financial institutions to foster economic growth and food sovereignty (Pokrant 2014; Nuruzzaman 2006). Commodification of peasant livelihoods brought about by these neoliberal policies resulted in new forms of capitalist accumulation and reshaped class relations in rural Bangladesh (Paprocki and Cons 2014). The social, political and environmental effects of such agrarian transitions have been well documented in the sociology and development literature, often dichotomising the society into poor and non- poor or providing descriptive narratives at aggregate level (Belton 2016; Adnan 2013; Swapan and Gavin 2011; Islam 2008). In this paper, we delve deeper into complexities of change and response, by explicitly looking at the livelihood implications on different wealth strata and framing the dynamic interactions in relation to emerging concepts within the adaptation literature.

In the sections that follow, we describe the socialecological changes in two selected villages that have undergone differential transformations in farming systems over the past few decades, and explore the livelihood adaptation responses of households disaggregated by wealth class. Our findings show that adaptation to social-ecological change occurs within a 'response space', whereby households' abilities to pursue successful livelihood pathways are constrained by the adaptive actions of other households, as well as their antecedent decisions that lock them in particular trajectories. While wealth determines the availability and effectiveness of alternative livelihood adaptation strategies for a given household, the consequences of these actions can influence the social and ecological contexts that set the conditions for subsequent actions by other households. We emphasise the need to address these complex interdependencies in policies and programmes designed to expand the adaptive capacities of households with varied needs.

\section{Social-ecological changes in the study sites}

The two study sites-Mithakhali village in Bagerhat district and Kamarkhola village in Khulna district - are located within the exposed coastal zone, close to the Sundarban mangrove forest (Fig. 1). Livelihood activities traditionally comprised of rainfed Aman ${ }^{1}$ paddy cultivation, supplemented with homestead vegetable gardening, livestock rearing and fishing as sources of subsistence (referred to as T0, Fig. 2). Since the early 1980s, growing interests in brackish water shrimp farming led to large-scale conversion of agricultural lands into shrimp ponds (locally referred to as 'gher'), where natural post-larvae were stocked at low density during the dry season, often without any supplementary feed (referred to as T1) (Rahman and Hossain 2013). In the beginning, shrimp farming was mainly carried out by outside businessmen and politicians, who used their power to appropriate public lands, clear mangrove areas and grab local farmers' lands (Nuruzzaman et al. 2001). Deliberate flooding of rice fields and canals with saline water, and legal and illegal construction of gates and pipelines through the embankments significantly increased

\footnotetext{
${ }^{1}$ In South Asia, the crop calendar is divided into Kharif - I (March - May), Kharif - II (June - November) and Rabi (December - February) and the paddy crops grown in these seasons are referred to as Aus, Aman and Boro, respectively.
} 


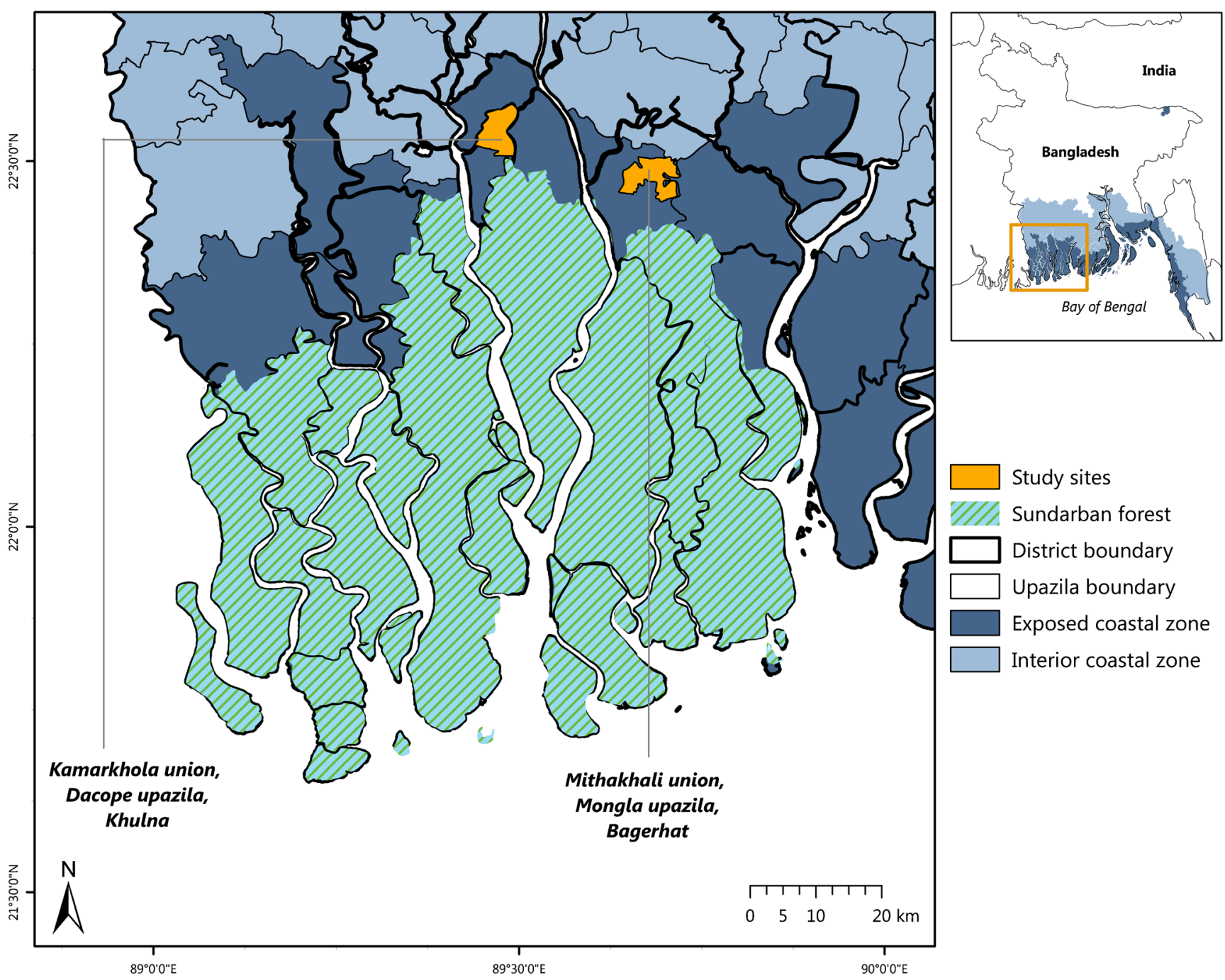

Fig. 1 Map of Bangladesh showing the two study villages

soil and water salinity, forcing many small landowners to stop rice cultivation and shift to shrimp, or to lease out their lands to large farmers (Islam 2008; Ali 2006). Over time, diminishing crop productivity, non-payment of lease money and disputes over common public lands led to increased social tensions, resulting in several incidences of violent conflicts among local farmers and outside entrepreneurs (Manju 1996; Nijera Kori 1996).

In Mithakhali, the locally elected lawmaker passed a law in 1996 stating "Jomi jar, gher tar" (only the true landowner has full rights over the shrimp farms on his land), enabling local farmers to regain control over their land. By this time, however, the 'golden era' of shrimp cultivation was almost over. Continued soil degradation, decrease in natural post-larvae populations and emergence of the white-spot viral syndrome led to massive declines in shrimp yield. To increase cash incomes, large farmers started to stock hatchery-bred post-larvae, add salts and fertilisers and extend the culture period. Reluctance to drain out saline water before the onset of monsoon, along with decreasing soil fertility, led to dwindling yields of paddy, which was gradually phased out and replaced with yearlong aquaculture of shrimp and white fish since the early 2000s (referred to as T2). The final blow came in 2007, when cyclone Sidr brought in highly saline tidal water and degraded the soil to such an extent that crop cultivation became impossible.

In Kamarkhola, shrimp cultivation was carried out by outside entrepreneurs and some local large farmers, with small farmers either leasing out their land or engaging in cooperative farming (referred to as T1). Like Mithakhali, the detrimental effects of the shrimp cultivation led to dissatisfaction among farmers and growing willingness to revert to the traditional subsistence-based farming system. In 2008, residents of Kamarkhola as well as other neighbouring villages united to chase away the outside entrepreneurs when they tried to open the sluice gates in the embankment. The newly elected local parliamentary member and grassroots anti-saline water environmental protection groups played key roles in mobilising 


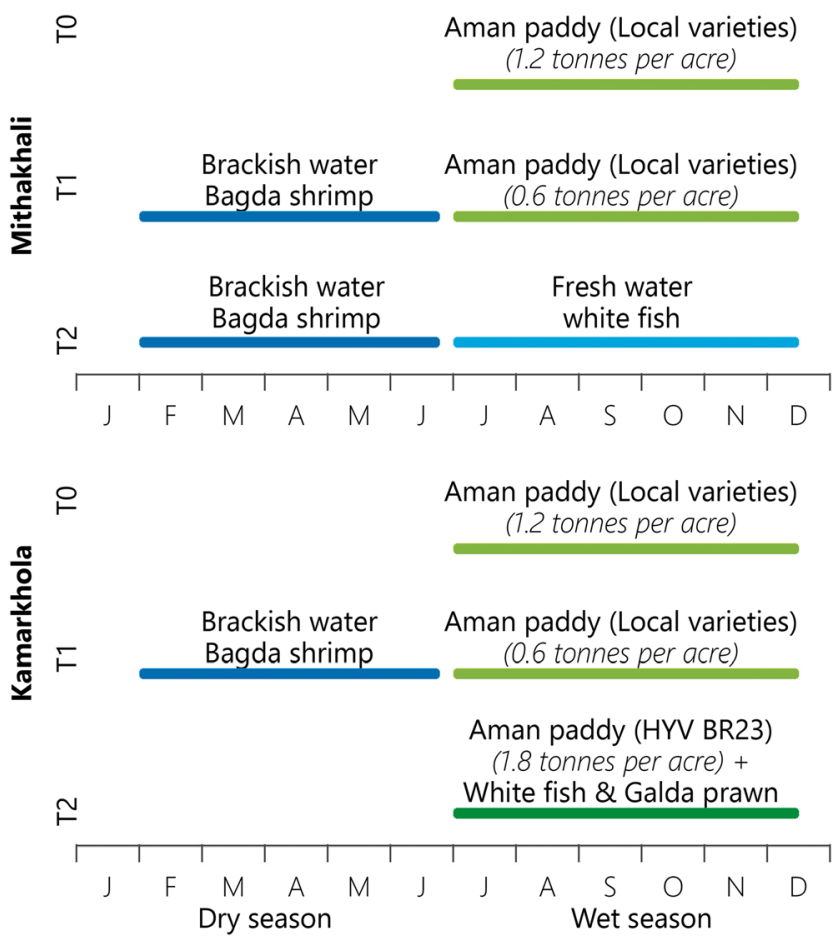

Fig. 2 Changes in farming systems in Mithakhali and Kamarkhola

farmers and helping them express their collective frustration against years of injustice. Finally, an order from the High Court permanently banned brackish water shrimp farming in Kamarkhola. In mid-2009, Kamarkhola was severely affected by cyclone Aila, which caused massive infrastructural damages, displacing people to temporary settlements on the embankment and prohibiting agricultural activities for about one and a half years. After agricultural activities resumed in 2011, most farmers obtained good yields from rice and some used their experience from shrimp farming to grow freshwater prawn and white fish as polyculture in ponds or as integrated culture on their agricultural lands (referred to as T2).

\section{Research methods}

Data collection was carried out in late 2014 using a mixedmethod approach, comprising of participatory wealth ranking (PWR), household questionnaire survey, focus group discussions (FGDs) and livelihood trajectory interviews. PWR was used to identify the number of wealth classes within each village and outline the main characteristics that differentiate one class from another. The exercise involved a group of 3-4 key informants, such as school teachers, local government members and mosque leaders, who had good knowledge on wealth distribution within the village. The household survey was administered to 150 households ( $25 \%$ of approximately 600 households) in each village, selected through a random route sampling method. Each of the villages was divided into neighbourhoods and within each neighbourhood households were selected via a 'random walk'. Household heads were the primary respondents; however, participation from any willing household member was welcomed to obtain more accurate data. The survey collected quantitative data on households' demographic profile, asset ownership, livelihood activities, perceptions on brackish water shrimp farming and changes in well-being.

Data from PWR and household survey were used to stratify households by wealth class. PWR participants in both villages disaggregated households into five wealth categories, namely, rich, upper middle, lower middle, poor and extreme poor, using agricultural land ownership as the most important determinant, along with indicators such as relative income, housing materials, education and food security (Online Resource 1). Asset ownership data from household surveys was then used to generate household wealth indices and calculate the numbers of sample households belonging to each of the five categories (Online Resource 1). Principal component analysis (PCA) was carried out using 17 indicators under seven dimensions (refer to Online Resource 1 for descriptive statistics). All components with eigenvalue $>1$ were extracted, of which the factor scores and factor loadings of the first principal component $\left(\mathrm{PC}_{1}\right)$ were considered as the household wealth indices and indicator weightages, respectively (Online Resource 1). Kmeans cluster analysis with five clusters was then applied on the $\mathrm{PC}_{1}$ factor scores to quantitatively disaggregate households into five wealth classes. Agricultural land ownership increased exponentially from the lowest to the highest wealth class, with the rich households possessing almost three times as much land as the upper middle class in both sites. This highlighted that a small percentage of households controlled a relatively large percentage of land, particularly in Mithakhali. Moreover, in both villages, the lower middle, poor and extreme poor classes were more homogenous in terms of their wealth indices, while the rich and upper middle class households exhibited high degree of within class variation (Online Resource 1).

Household survey data was also used to identify the livelihood activities pursued by households of different wealth classes both at the time of the study (T2) and before the changes in farming systems (T1) in the two villages (Tables 1 and 2). While it was relatively straightforward to collect information on the livelihood activities of all household members in T2, recalling similar information for $\mathrm{T} 1$ proved to be challenging in certain cases. These challenges mainly related to two issues: firstly, the 'before' time period referred to a range of years (that is, 1015 years ago) rather than a particular year; and secondly, in some cases, the household demographic structure changed between the two time periods, due to marriage, birth or death, with consequent changes in number of income generating members. Additional questions were often asked to address these issues and a representative scenario was constructed in such cases.

Two separate male and female FGDs were conducted in each village, with each FGD involving 8-10 adult participants from different wealth classes. The FGDs provided an 
Table 1 Livelihood strategies pursued by households of different wealth classes in Mithakhali before and after the changes in farming systems

\begin{tabular}{|c|c|c|c|c|c|c|}
\hline & $\begin{array}{l}\text { Wealth status } \\
\text { No. of households surveyed (Total-150) }\end{array}$ & $\begin{array}{l}\text { Rich } \\
8(5.3 \%)\end{array}$ & $\begin{array}{l}\text { Upper middle } \\
17(12 \%)\end{array}$ & $\begin{array}{l}\text { Lower middle } \\
51(34 \%)\end{array}$ & $\begin{array}{l}\text { Poor } \\
49(32.7 \%)\end{array}$ & $\begin{array}{l}\text { Extreme poor } \\
25(16.7 \%)\end{array}$ \\
\hline \multirow[t]{4}{*}{ Indicators of wealth } & Mean agricultural land (decimals) & 2253 & 736 & 378 & 143 & 4.22 \\
\hline & Mean homestead land (decimals) & 149 & 65.9 & 32.5 & 28.9 & 5.48 \\
\hline & Mean pond area (decimals) & 42.9 & 13.7 & 9.8 & 10.7 & 3.3 \\
\hline & Education ( $\%$ of adults with SSC degree or above) & 46.7 & 29.3 & 26.4 & 20.1 & 8.39 \\
\hline \multirow{22}{*}{$\begin{array}{l}\text { Main livelihood activities } \\
\text { (\% of households engaged } \\
\text { in each activity) }\end{array}$} & T1 (mid-1980s to mid-2000s) & & & & & \\
\hline & Aman paddy in own land (wet season) & 100 & 100 & 100 & 90 & 17 \\
\hline & Bagda shrimp in own land (dry season) & 100 & 94 & 88 & 60 & 9 \\
\hline & White fish in own pond & 100 & 100 & 92 & 84 & 78 \\
\hline & Small business & 43 & 22 & 12 & 20 & 30 \\
\hline & Service/ salaried job & 14 & 17 & 6 & 20 & 4 \\
\hline & Wage labour & 0 & 6 & 19 & 22 & 91 \\
\hline & Homestead gardening (good yield) & 100 & 100 & 96 & 94 & 30 \\
\hline & Open access fishing & 43 & 56 & 83 & 74 & 91 \\
\hline & T2 (mid-2000s to present) & & & & & \\
\hline & Aman paddy in own land (wet season) & 43 & 11 & 8 & 6 & 0 \\
\hline & Bagda shrimp and white fish in own land (yearlong) & 100 & 94 & 88 & 86 & 13 \\
\hline & Land rent & 43 & 39 & 25 & 16 & 0 \\
\hline & White fish in own pond (consumption) & 71 & 72 & 77 & 78 & 83 \\
\hline & White fish in own pond (consumption and sale) & 29 & 28 & 19 & 22 & 0 \\
\hline & Bagda shrimp in own pond & 29 & 50 & 56 & 42 & 0 \\
\hline & Small business & 86 & 11 & 27 & 32 & 39 \\
\hline & Service/salaried job & 14 & 39 & 15 & 34 & 9 \\
\hline & Wage labour & 0 & 0 & 8 & 22 & 78 \\
\hline & Homestead gardening (very low yield) & 7 & 15 & 43 & 33 & 4 \\
\hline & Open access fishing & 0 & 0 & 35 & 32 & 61 \\
\hline & Motorcycle or van driver & 0 & 6 & 8 & 2 & 26 \\
\hline
\end{tabular}

1 acre $=100$ decimals

overview of the changes in livelihoods over the past four decades with detailed discussion on the underlying causes and impacts of these changes on different groups. Livelihood trajectory interviews were carried out with 25 adult males and females selected through a purposive sampling method, ensuring representation from all wealth classes and different occupations in each of the villages. The interviews followed an 'unstructured' format, whereby a biographical or narrative approach was adopted to collect contextspecific in-depth information on individuals' current and past livelihood activities, changes in ownership or access to productive resources, the opportunities and barriers related to pursuing desired livelihood activities, their hopes, values and fears and changes in well-being. Analysis of qualitative data from the FGDs and interviews involved transcription and translation of field notes and audio recordings, coding, identification of themes and sub-themes and then linking these to theoretical concepts and sorted as per the research objectives. The OBLs were identified and structured into eight broad categories for analytical clarity.

\section{Results}

\section{Livelihood adaptation to social-ecological changes}

The changes in farming systems had differential impacts on the livelihoods of households of different wealth classes. Rich and upper middle class households, endowed with large amounts of agricultural land, usually wanted to specialise in one activity that had high economic returns. In Mithakhali, land-based aquaculture was the primary income source for these households in T2. They usually owned large farms combining own and leased in lands, and engaged in small or large business, mostly related to fish trade, which served as their secondary income source. Larger land ownership often led to differences in topography and soil quality among different land parcels, which provided opportunities for planting paddy in small portions of high level land. Wealthier households in Kamarkhola also preferred shrimp cultivation; since the latter had been banned in T2, they engaged in large-scale 
Table 2 Livelihood strategies pursued by households of different wealth classes in Kamarkhola before and after the changes in farming systems

\begin{tabular}{|c|c|c|c|c|c|c|}
\hline & $\begin{array}{l}\text { Wealth status } \\
\text { No. of households surveyed (Total - 150) }\end{array}$ & $\begin{array}{l}\text { Rich } \\
10(6.7 \%)\end{array}$ & $\begin{array}{l}\text { Upper middle } \\
11(4.3 \%)\end{array}$ & $\begin{array}{l}\text { Lower middle } \\
58(38.7 \%)\end{array}$ & $\begin{array}{l}\text { Poor } \\
40(26.7 \%)\end{array}$ & $\begin{array}{l}\text { Extreme poor } \\
31(20.7 \%)\end{array}$ \\
\hline \multirow[t]{4}{*}{ Indicators of wealth } & Mean agricultural land (decimals) & 1554 & 597 & 220 & 57.8 & 6.87 \\
\hline & Mean homestead land (decimals) & 65.50 & 43.55 & 22.69 & 11.48 & 7.74 \\
\hline & Mean pond area (decimals) & 23.8 & 21.5 & 11.7 & 4.53 & 0.74 \\
\hline & Education ( $\%$ of adults with SSC degree or above) & 60.0 & 63.6 & 46.1 & 35.0 & 15.8 \\
\hline \multirow{24}{*}{$\begin{array}{l}\text { Main livelihood activities } \\
\text { (\% of households engaged } \\
\text { in each activity) }\end{array}$} & \multicolumn{6}{|c|}{ T1 (late-1980s to 2008) } \\
\hline & Aman paddy in own land (wet season) & 80 & 100 & 95 & 78 & 6 \\
\hline & Bagda shrimp in own land (dry season) & 70 & 73 & 66 & 50 & 13 \\
\hline & Land rent (dry season) & 40 & 45 & 45 & 33 & 3 \\
\hline & White fish in own pond (consumption) & 50 & 73 & 45 & 60 & 23 \\
\hline & Bagda shrimp in own pond & 40 & 64 & 54 & 26 & 29 \\
\hline & Small business & 20 & 18 & 24 & 35 & 23 \\
\hline & Service/salaried job & 30 & 18 & 21 & 15 & 10 \\
\hline & Wage labour & 0 & 0 & 16 & 65 & 90 \\
\hline & Homestead gardening (very low yield) & 80 & 73 & 76 & 63 & 65 \\
\hline & Open access fishing & 10 & 9 & 33 & 53 & 39 \\
\hline & \multicolumn{6}{|c|}{ T2 (2009 to present) } \\
\hline & Aman paddy in own land (wet season) & 80 & 100 & 100 & 80 & 3 \\
\hline & Share-cropping (wet season) & 0 & 0 & 9 & 18 & 42 \\
\hline & Land rent (wet season) & 60 & 18 & 5 & 0 & 0 \\
\hline & White fish in own pond (consumption) & 50 & 45 & 74 & 68 & 52 \\
\hline & White fish in own pond (consumption and sale) & 30 & 45 & 22 & 10 & 3 \\
\hline & Galda prawn in own pond & 40 & 72 & 61 & 25 & 26 \\
\hline & Small business & 20 & 36 & 16 & 23 & 13 \\
\hline & Service/salaried job & 30 & 27 & 26 & 18 & 10 \\
\hline & Wage labour & 0 & 9 & 21 & 68 & 90 \\
\hline & Open access fishing & 10 & 36 & 72 & 78 & 87 \\
\hline & Homestead gardening (good yield) & 100 & 100 & 98 & 93 & 74 \\
\hline & Motorcycle or van driver & 0 & 0 & 5 & 3 & 3 \\
\hline
\end{tabular}

1 acre $=100$ decimals

Galda prawn and paddy cultivation or leased out their land for sharecropping. Paddy cultivation requires greater investment of time and labour, with relatively lower incomes, making it less appealing for large farmers.

"I inherited only 5 acres, but today I have 30 acres of land separated in 4-5 parcels. I have three shrimp farms of 10 acres, 6 acres and 3 acres, which I manage on my own. The rest of the land is either leased out or used for cooperative shrimp farming. Although profits from aquaculture are now decreasing, I don't have much problem because I have my own farms. I don't have to pay rent and can use my savings for investment. Financially I'm better off than before. I also have a shop in the village market, which I have rented out. I'm a primary school drop-out, but my sons are attending college." - Upper middle class farmer, Mithakhali.
With comparatively less land, lower middle class households tried to diversify their farm activities and engage in small businesses or service. In Mithakhali, these households were mostly involved in aquaculture, with $52 \%$ having own small farms, $13 \%$ having own large farms together with land leased in from others and $21 \%$ being part of co-operative farms. Most households also farmed Bagda shrimp and white fish in their ponds, often at a small-scale. In T2, all lower middle class households in Kamarkhola grew paddy and white fish for consumption or sale, with many trying out Galda prawn. Unlike those in Mithakhali, Kamarkhola households could get good yields of vegetables and fruits grown in homestead gardens.

"I cultivate Aman paddy on 2 acres of land, along with freshwater Galda prawn and white fish, and vegetables on the dykes. I feel that this integrated system is more 
sustainable and profitable, as Galda prawn and white fish are relatively less susceptible to diseases compared to Bagda shrimp. I use another 1.2 acres of land for paddy cultivation only. Fish farming requires regular supervision; since that land is quite far away from my home, I cannot go there every day. I also have a grocery store at the local market. Four years ago, I borrowed BDT 50,000 from a NGO, which I repaid in ten instalments of BDT 5000 each along with BDT 1000 as interest. During the shrimp cultivation period, I was also involved in Bagda farming for about 10 - 12 years, like other farmers in the village. However, I faced significant losses due to virus outbreaks in my farm. I'm very happy that shrimp cultivation has been banned in this area. Now the environment is much better." - Lower middle class farmer, Kamarkhola.

Poor and extreme poor households had limited or no agricultural and homestead land, which restricted their livelihood options. Like other classes, these households also engaged in paddy, vegetable, shrimp and white fish farming; however, such diversification hardly allowed way out of deprivation, as capital and cash constraints limited the scale of these activities. Petty trades and wage-labouring activities, either within or outside the sub-district, were main sources of cash income. In Mithakhali, these households engaged in buying shrimp from farms and selling them to the market, driving vans to transport shrimp or collecting wild post-larvae and fish juveniles and selling them to farmers. In Kamarkhola, some of these households worked as sharecroppers, paying half of the crops to the land owners as rent.

"Poor people like us have to do a bit of everything to survive. I have leased in 0.66 acres of land from my aunt, for which I pay an annual rent of BDT 10,000. In February-March, I released 21,000 post-larvae in 11 batches at a cost of BDT $600-900$ per 1,000 post-larvae. But viral attacks killed most of them; I lost my investment and now I don't know how I'll pay the rent or repay the loans. In June, I also invested BDT 16,000 to release $111 \mathrm{~kg}$ of white fish in my small pond $(0.45$ acres) for consumption as well as sale; they are my last hope. During December-January, I grow some vegetables in my homestead garden and from April-June, I harvest shrimps from others' farms." - Poor farmer, Mithakhali.

\section{Adaptation opportunities, barriers and limits}

As discussed above, livelihood adaptive capacities largely depended on the households' wealth status and the predominant farming system in the village, thus, indicating economic, ecological and socio-political factors as the most important OBLs for adaptation. These factors determined the capacity of households to shape social-ecological change in desirable ways, which, in turn, affected the main livelihood options available to different households. Institutional support, infrastructural developments, market access and knowledge on farming practices posed additional OBLs in effectively executing the available livelihood options. These OBLs interacted in different ways, whereby a given OBL can reinforce or dampen another OBL directly or indirectly via its effects on related livelihood activities. The different OBLs had heterogeneous impacts on households of different wealth classes, such that the same conditions facilitated adaptation by one group while restricting the adaptive capacity of another (Online Resource 2 and Table 3).

Lack of freshwater for irrigation and high levels of soil salinity traditionally posed ecological limits to Boro and Aus paddy cultivation during the dry season; however, the same conditions later provided opportunities for brackish water shrimp cultivation in the coastal region. Profits from shrimp farming enabled farmers to further increase their land ownership, particularly at a time when land prices were lower. Of the 150 sampled households in Mithakhali, 30\% had purchased land in the last three decades, although the quantity varied significantly from 0.66 to 38 acres, with a median of 1.32 acres. If disaggregated by wealth status, $71 \%$ of the rich households, $44 \%$ of the upper middle class households, $37 \%$ of the lower middle class households and $24 \%$ of the poor households had purchased agricultural land. Thus, many of the better-off households were in their current wealth status because of land accumulation in the past. The power imbalances in society, resulting from unequal resource ownership and a widening poverty gap, suffocated the agency of poorer households to undertake their desired livelihood strategies while enhancing the ability of the richer ones to pursue their preferred trajectories. The land use change in Mithakhali during T2 was largely influenced by the rich and upper middle class households, who refused to drain out saline water at the end of the dry season, restricting other farmers to grow paddy.

The transition to aquaculture in T2, coupled with the tidal surges brought in by cyclones Sidr and Aila, exacerbated soil fertility, with subsequent impacts on homestead gardening and livestock rearing. Large farmers also blocked canals and brought them under private control, which prohibited poor people from catching fish for subsistence. Thus, for wealthier households, ecological opportunities, in terms of high shrimp yields in T1, translated to economic opportunities, that is, increased land ownership. This, in turn, influenced the sociopolitical landscape, creating ecological barriers for subsistence-based activities in $\mathrm{T} 2$.

Disease outbreaks in shrimp farms created an additional ecological barrier in $\mathrm{T} 2$, which disproportionately affected the poorer households. Shrimp mortality had increased 
Table 3 Opportunities, barriers and limits experienced by households of different wealth classes with respect to specific livelihood options

\begin{tabular}{|c|c|c|c|c|c|c|c|}
\hline Site & SI & Livelihood adaptation options & Rich & $\begin{array}{l}\text { Upper } \\
\text { middle }\end{array}$ & $\begin{array}{l}\text { Lower } \\
\text { middle }\end{array}$ & Poor & $\begin{array}{c}\text { Extreme } \\
\text { poor }\end{array}$ \\
\hline \multirow{14}{*}{ 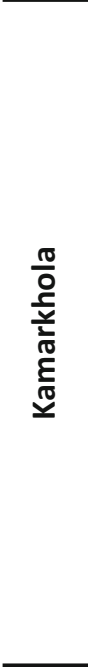 } & 1 & Semi-intensive shrimp cultivation & & & & & \\
\hline & 2 & Freshwater prawn in pond & & & & & \\
\hline & 3 & Temporary labour migration & & & & & \\
\hline & 4 & Prawn-carp-paddy farming in land & & & & & \\
\hline & 5 & Livestock rearing & & & & & \\
\hline & 6 & Homestead gardening & & & & & \\
\hline & 7 & Rain-fed Aman paddy cultivation & & & & & \\
\hline & 8 & Service jobs within/outside village & & & & & \\
\hline & 9 & Sharecropping & & & & & \\
\hline & 10 & Fishing in open-access canals & & & & & \\
\hline & 11 & Winter/ dry season crops & & & & & \\
\hline & 12 & Small-scale business & & & & & \\
\hline & 13 & Van or motorcycle driving & & & & & \\
\hline & 14 & Brackish water shrimp cultivation & & & & & \\
\hline \multirow{12}{*}{ 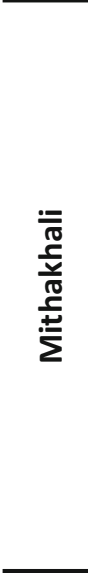 } & 15 & Semi-intensive shrimp cultivation & & & & & \\
\hline & 16 & Leasing out land & & & & & \\
\hline & 17 & Shrimp-carp farming in land & & & & & \\
\hline & 18 & Temporary labour migration & & & & & \\
\hline & 19 & Van or motorcycle driving & & & & & \\
\hline & 20 & Service jobs within/outside village & & & & & \\
\hline & 21 & Small-scale business & & & & & \\
\hline & 22 & Fishing in open-access canals & & & & & \\
\hline & 23 & Aman paddy cultivation & & & & & \\
\hline & 24 & Livestock rearing & & & & & \\
\hline & 25 & Homestead gardening & & & & & \\
\hline & 26 & Sharecropping & & & & & \\
\hline \multicolumn{8}{|c|}{ Legend } \\
\hline \multicolumn{8}{|c|}{ Opportunity } \\
\hline \multicolumn{8}{|c|}{ Barrier (Low) } \\
\hline \multicolumn{8}{|c|}{ Barrier (High) } \\
\hline \multicolumn{8}{|c|}{ Limit } \\
\hline \multicolumn{8}{|c|}{ Unwilling to undertake due to wealth status } \\
\hline
\end{tabular}

from 5 to $80 \%$ over the last 15 years, and at the time of study, a farmer could earn about $\mathrm{BDT}^{2} 17,000$ per acre (compared to BDT 138,000 per acre in the past) during the dry season, followed by another BDT 27,000 per acre from white fish farming during the wet season. However, given that the mean agricultural land ownership of poor and extreme poor households, who together comprised $68 \%$ of the total population, was only 1.42 and 0.04 acres respectively, the cash income from aquaculture was very limited for most people. At the same time, farmers were

\footnotetext{
${ }^{2}$ United States Dollar (USD) $1 \approx$ Bangladeshi Taka (BDT) 80
}

deprived of all other sources of subsistence, such as rice, vegetables, fish and livestock.

Most farmers tried to cope with losses by increasing stocking frequency, leaving the results to fate. Farmers had little knowledge on the causes of disease outbreaks, often referring to imported post-larvae or poor handling as probable reasons. Even those who applied supplementary feed or fertilisers to improve soil quality did so on a trial and error basis, without any proper guidelines. The local fisheries or agricultural department seemed incapable of addressing farmers' queries about shrimp diseases or soil quality, thus, creating knowledge barriers. Inspired by success stories from other districts, some 
wealthier farmers expressed interests in shifting from the existing improved extensive to semi-intensive shrimp farming - a culture system that was abandoned in the country following the white-spot virus epidemics in the mid-1990s.

Presence of good land and labour markets enabled households to better utilise their human capital and often avoid the risks associated with shrimp farming. Educated people could engage in service jobs within or outside the village, while earning fixed incomes from land rent. As wage labouring and sharecropping opportunities generally decreased in $\mathrm{T} 2$, male members from poor and extreme poor households often migrated to adjacent sub-districts, where cultivation of three paddy crops a year created demand for labour. Recent infrastructural developments, in terms of roads, transport facilities and power supply, and proximity to important market hubs, also increased opportunities for van/motorcycle driving and small-scale businesses. Thus, $24 \%$ of the adult males in Mithakhali were exclusively involved in business and 23\% were farmers cum businessmen. In contrast, in Kamarkhola, only $5 \%$ of adult males were engaged in business and $12 \%$ in agriculture cum business.

In Kamarkhola, the percentage of households that had bought land and the amount of land purchased were comparatively lower than that of Mithakhali. In the past three decades, only $17 \%$ of the sampled households ( $40 \%$ of the rich and upper middle class combined and $23 \%$ of the lower middle class households) had purchased between $0.08-1$ acres of agricultural land, with a median value of 0.66 acres. The market demand for land was lower in Kamarkhola because of its remote location with poor physical access to regional market hubs. The relatively lower inequality in wealth in Kamarkhola, coupled with good leadership, provided sociopolitical opportunities for mobilising against large shrimp farmers. The 2009 cyclone Aila proved to be a 'blessing in disguise' as it brought the area under limelight. The government, international donors and NGOs provided relief materials in the immediate aftermath of the cyclone and helped in the rehabilitation process. The survey showed that $11 \%$ of households had their houses re-built by NGOs, while $93 \%$ received monetary aid (BDT 20,000) from the government. Since $2012,31 \%$ of households received training in disaster preparedness and $52 \%$ of households benefitted from improved water supply and sanitation facilities. While farmers in Mithakhali were concerned about the immediate difficulties of stopping shrimp cultivation, those in Kamarkhola could depend on cyclone aid during the transition period.

Following the ban, soil quality improved substantially in the past 5 years. However, continuous inundation of land for months after Aila had different effects on land based on its location. While some farmers benefitted from silt deposition, others suffered from layers of sand deposited by tidal waters (cf. satellite images of Kamarkhola union presented in Auerbach et al. (2015)). The ban had opened diverse livelihood opportunities for smallholding farmers, who could now engage in integrated paddy-prawn-fish farming on land and prawn-fish polyculture in homestead ponds.

In T2, some of the rich and upper middle class households leased out large portions of their land for paddy cultivation, which created sharecropping opportunities for the poor and extreme poor households. Despite the ban, a few large farmers were using their political contacts to illegally cultivate shrimp by releasing saline water from underground aquifers and holes in the embankment. Bagda shrimp and Galda prawn have different requirements, in terms of farm management techniques, optimum salinity and temperatures, stocking densities and application of supplementary feed. As such, some farmers in Kamarkhola reported lack of experience and knowledge on freshwater prawn aquaculture as a barrier to earning good profits.

"In 2013, I borrowed BDT 160,000 to excavate my pond and start prawn-white fish polyculture, but I didn't earn any profits in the first season because of limited knowledge on the ratio of prawn to fish to be released, optimum water temperature, salinity and depth and harvesting times. In the second season, I consulted my relatives from Batiaghata, where farmers earn as much as BDT 300,000 per season. If I become successful this time, other farmers in the area are likely to follow." Poor farmer, Kamarkhola.

Institutional support in the post-cyclone rehabilitation period increased availability of credit, thus, providing economic opportunities for investing in new activities. During 2013 $2014,40-50 \%$ of the rich and upper middle class households and $60-80 \%$ of the lower middle, poor and extreme poor ones had taken loans for several purposes, such as for investment in paddy cultivation (14\%), investment in fish farming (9\%), education of children (12\%) and starting new businesses $(5 \%)$. While the wealthier households mainly resorted to banks or relatives, poorer households almost entirely depended on NGOs, which had comparatively higher interest rates. Lack of assets posed a barrier to accessing formal financial institutions that required collaterals for disbursing loans. In contrast, in Mithakhali, only 18\% households had taken loans, mainly for investment in fisheries (11\%) and businesses (3\%). Although farmers in Mithakhali had access to credit, they were reluctant to borrow as they feared becoming indebted due to shrimp disease outbreaks.

In Kamarkhola, the lack of power supply and road connection with nearby sub-districts posed an infrastructural barrier to the development of shops and businesses, as well as van pulling or motorcycle driving opportunities that were available in Mithakhali. While paddy cultivation was the main livelihood activity in both $\mathrm{T} 0$ and $\mathrm{T} 2$, wage-labouring opportunities were considerably lower in $\mathrm{T} 2$, due to overall 
population growth, decreased land ownership per household and use of machines for ploughing in place of cattle. Thus, similar to Mithakhali, seasonal migration to nearby subdistricts was common among poor and extreme poor households. However, poor health and lack of adult male members created additional barriers for some of these households.

\section{Discussion}

This paper explored the livelihood adaptation dynamics and the differential OBLs experienced by households of different wealth classes in coastal Bangladesh. Analysis of empirical evidence shows that households' livelihood strategies and outcomes are strongly related to their wealth status, with agricultural land ownership being the most important determinant. While rich and upper middle class households, with large land endowments, typically preferred to specialise in a couple of high-return farm and non-farm activities, the lower middle class sought to diversify their farm activities often with engagement in small business or fixed income jobs. The poor also tried to diversify, but the limited scale of each activity prohibited them from obtaining positive results. The poor and extreme poor, with negligible land and a lack of specialised skills, mainly depended on wage-labouring activities and petty trades.

While wealth dictates the availability of productive resources and alternative livelihood options, it also acts as a source of social power, allowing powerful stakeholders to drive social-ecological change in ways that are desirable for some, but detrimental to others. The transformations of farming systems in the two study villages exhibit the exercise of power, both in its overt and covert forms. During T1, outside entrepreneurs including businessmen, politicians, army and civil officials used their wealth, political ties and musclemen to forcefully grab local land for shrimp farming and control the operation of sluice gates as per their water exchange needs. Following the eviction of these outside entrepreneurs in $\mathrm{T} 2$, large local landowners indirectly forced smallholding farmers to abandon paddy cultivation by degrading soil fertility through seepage of saline water. Thus, path dependency, vested interests and power dynamics can silently shape the adaptation landscape.

The findings emphasise that adaptation is a complex, dynamic process occurring through linear time, where key decision-making points influence the direction of change and responses based on evaluation of past outcomes and future goals. Isolated focus on impacts and proximate responses often indicate increases in wealth can enhance adaptive capacity. Such narrow views can promote policies directed towards aggregate economic growth, which can further exacerbate inequalities in resource distribution. To provide a holistic understanding, it is essential to engage with the interactions between the differential adaptation pathways of multiple actors with different power, values and interests. A broader view can recognise the need to invest in governance and institutions that are instrumental to overcoming these power dynamics. The ban on brackish water shrimp farming in Kamarkhola and the increased external support in the post-cyclone period testify the roles of governance and institutions in fostering equitable livelihood opportunities.

The term 'differential livelihood adaptation', as used in this study, closely relates to the concepts of 'divergent adaptation' (Snorek et al. 2014), 'response space' (Osbahr et al. 2010) and 'adaptation pathway' (Wise et al. 2014; Haasnoot et al. 2013) - all of which conceptualise adaptation as a localised, complex and dynamic process, framed by the social, political and institutional dynamics as well as power, knowledge and values/interests across multiple scales. Households operate within a shared response space, characterised by adaptive and maladaptive spaces - the boundaries between which are changing over time, due to changes in bio-physical, socioeconomic and institutional context. Positive outcomes from past livelihood strategies can allow some households to experience upward trajectories, thus, widening their adaptation space. Wealthier households in Mithakhali, for example, accumulated large amounts of land using profits from shrimp farming, which, in turn, enabled them to cope with dwindling shrimp yield by investing in high-return non-farm activities or engaging in different forms of farming arrangements. On the other hand, the adaptation spaces of some poorer households narrowed down further due to sale or division of inherited land, shrimp disease outbreaks, and inability to pursue subsistence-based livelihoods. Households, thus, exhibit divergent adaptation, whereby successful adaptation by one wealth class led to reduced adaptive capacity of another wealth class within a shared social-ecological system (cf. Snorek et al. 2014).

Households' adaptation spaces are also modified by a number of other OBLs; however, the extent to which these OBLs affect different households depend on the specific livelihood activities being considered and the differential values and interests they hold. Brackish water shrimp cultivation may pose a barrier to a landless farmer willing to engage in sharecropping, but serve as an opportunity for another landless farmer working on a fixed income job as a farm guard. Similarly, prohibiting entry of saline water within the embanked areas can create opportunities for paddy cultivation for small farmers, but hinder large farmers from generating optimum income from their land through shrimp aquaculture. These lead to questions on 'what is a barrier, in what circumstance, and for whom'. Issues of scale are also important; the availability of low-lying land proximate to the coast and abundance of mangrove resources served as a huge potential for overall development of the south-western coastal region and the country as a whole. This justifies the earlier policies that supported national growth and agricultural 
productivity through construction of coastal embankments. However, the benefits of these actions were enjoyed by a small proportion of farmers, increasing the inequalities in wealth at local level (Johnson et al. 2016; Pouliotte et al. 2009).

These inequalities have grave implications for future adaptation to climate change. Analyses of regional census, satellite and soil salinity data have revealed strong associations between salinity, poverty and food insecurity, mediated through the loss of crops and diversified livelihood opportunities (Johnson et al. 2016; Szabo et al. 2016). Although shrimp cultivation is often touted as an effective adaptation to salinisation and climate change, it has no significant relationship with poverty reduction at local level, as most of the profits are reaped by a few, often absentee, farmers (Johnson et al. 2016). On the contrary, continuation of brackish water shrimp farming, and associated mangrove clearance, river siltation and land subsidence within polders, are likely to push the salinity front further inwards, and exacerbate ecosystem regulating services, such as water quality maintenance and hazard protection (Abdullah et al. 2016; Faruque et al. 2016; Hossain et al. 2016). Thus, to ensure resilient livelihoods and equitable distribution of well-being, processes of incremental or transformational adaptation should account for the needs of different stakeholders.

\section{Conclusion}

Sustainable and equitable livelihood options are of utmost importance in enabling households with different wealth endowments to cope with increased exposure to shocks and stresses. Appropriate implementation of government policies and support from local government and non-governmental organisations are essential in reducing some of the adaptation barriers and fostering livelihood outcomes for different groups. In Kamarkhola, the ongoing shift towards a riceprawn-fish integrated system is both ecologically and economically viable; however, successful transition requires training and information support, which needs to be provided by local government institutions and NGOs. This, in turn, requires increased communication with scientists and researchers, to build the capacity of agricultural and fisheries departments (cf. Hasanuzzaman et al. 2011; Chandra et al. 2010; Ali et al. 2009). Availability of low-interest credit is also essential, but most farmers showed reluctance to take loans unless they were confident that they would be able to produce enough yield to repay the loans. Research has shown that borrowing from a variety of sources to overcome cash shortages, coupled with lower capacity to reimburse loans, had led to higher indebtedness and potential poverty traps (GehlichShillabeer 2008). Thus, provision of micro-credit, in absence of knowledge support, may not lead to better livelihood outcomes.
The farming system trajectory undertaken by farmers in Mithakhali seems to be maladaptive in the context of increasing salinity and environmental degradation. The agroecosystem has almost reached a limit; according to local farmers, the farmlands might lose all productive capacity unless some major transformations allow the soil to recuperate. However, this does not mean that sustainable shrimp and fish aquaculture is not possible; it requires numerous technological improvements, adequate knowledge transfer through institutional changes and appropriate monitoring of compliance with social and environmental requirements (Paul and Vogl 2011). The importance of shrimp export in promoting national growth is well recognised and the government has enacted a number of laws and policies with respect to allocation of areas, conservation of natural biodiversity, shrimp production and handling procedures and safeguarding the rights of local people (MOFL 2014). However, weaknesses in institutions and their capabilities created huge gaps in enforcement and allowed the powerful to pursue their vested interests (Paul and Vogl 2011; Alam et al. 2005).

Low-lying coastal areas in Bangladesh, and elsewhere, are prone to a range of shocks and stresses; however, the rich natural capital of these regions can promote a range of ecologically and economically viable livelihood options, provided that conflicts between multiple resource users do not lead to environmental degradation and restrict the adaptation options for poorer households. Compared to other Asian countries, which practice semi-intensive and intensive shrimp/prawn farming, Bangladeshi farmers are still dependent on extensive and improved extensive methods. There is huge potential to increase production by adopting best practice from other countries like China, Thailand, Indonesia and Vietnam (Joffre et al. 2010). If Bangladesh seeks to increase yield by promoting intensive and semi-intensive methods, it must take adequate precautions to avoid the adverse effects experienced by other countries, particularly in terms of discharging antibiotics, fertilisers and other chemicals into adjacent water bodies (e.g. Hatje et al. 2016; Herbeck et al. 2013). Promotion of such culture methods may further exacerbate wealth inequalities in coastal Bangladesh, as small farmers do not have the financial capital necessary for investment.

Good leadership, proper implementation of policy guidelines, infrastructural development, better institutional support and knowledge dissemination can enable households with comparatively lower entitlements to generate optimum incomes in ways that do not jeopardise their future livelihoods. The Government of Bangladesh, with support from donor organisations, is embarking on a number of policies and projects involving infrastructural and institutional development (e.g. Coastal Embankment Improvement Project, funded by the World Bank; Blue Gold Program, funded by the Government of the Netherlands; National Land Zoning Project, implemented by the Ministry of Land) (General Economics Division 2015). 
Building on past experiences and evidence-based research, these interventions aim to reduce disaster impacts, enhance livelihoods, and protect environmental resources over the long term.

Acknowledgements This paper is part of a $\mathrm{PhD}$ study, funded by the Leeds International Research Scholarship (LIRS) and the Sustainability Research Institute (SRI) fieldwork bursary, University of Leeds, UK. The authors declare that they have no conflict of interest.

Open Access This article is distributed under the terms of the Creative Commons Attribution 4.0 International License (http:// creativecommons.org/licenses/by/4.0/), which permits unrestricted use, distribution, and reproduction in any medium, provided you give appropriate credit to the original author(s) and the source, provide a link to the Creative Commons license, and indicate if changes were made.

\section{References}

Abdullah AN, Myers B, Stacey N, Zander KK, Garnett ST (2016) The impact of the expansion of shrimp aquaculture on livelihoods in coastal Bangladesh. Environ Dev Sustain 1-22. doi:10.1007/ s10668-016-9824-5

Adnan S (2013) Land grabs and primitive accumulation in deltaic Bangladesh: interactions between neoliberal globalization, state interventions, power relations and peasant resistance. J Peasant Stud 40(1):87-128. doi:10.1080/03066150.2012.753058

Alam SN, Lin CK, Yakupitiyage A, Demaine H, Phillips MJ (2005) Compliance of Bangladesh shrimp culture with FAO code of conduct for responsible fisheries: a development challenge. Ocean Coast Manag 48(2):177-188. doi:10.1016/j.ocecoaman.2005.01.001

Ali AMS (2006) Rice to shrimp: land use/land cover changes and soil degradation in southwestern Bangladesh. Land Use Policy 23(4): 421-435. doi:10.1016/j.landusepol.2005.02.001

Ali MA, Hossain GS, Biswas M, Barman S, Huq K (2009) Polyculture and integrated culture pattern of freshwater prawn in fresh to hyposaline water. Int J Sustain Crop Prod 4(4):23-27

Antwi-Agyei P, Dougill AJ, Stringer LC (2015) Barriers to climate change adaptation: evidence from northeast Ghana in the context of a systematic literature review. Clim Dev 7(4):297-309. doi:10. 1080/17565529.2014.951013

Auerbach L, Goodbred S Jr, Mondal D, Wilson C, Ahmed K, Roy K, Steckler M, Small C, Gilligan J, Ackerly B (2015) Flood risk of natural and embanked landscapes on the Ganges-Brahmaputra tidal delta plain. Nat Clim Chang 5(2):153-157. doi:10.1038/ NCLIMATE2472

Belton B (2016) Shrimp, prawn and the political economy of social wellbeing in rural Bangladesh. J Rural Stud 45:230-242. doi:10. 1016/j.jrurstud.2016.03.014

Bryan E, Deressa TT, Gbetibouo GA, Ringler C (2009) Adaptation to climate change in Ethiopia and South Africa: options and constraints. Environ Sci Pol 12(4):413-426. doi:10.1016/j.envsci. 2008.11.002

Chandra K, Chowdhury A, Das D (2010) Shrimp culture practices at farmers' level in Bagerhat District. Progress Agric 21(1-2):173185. doi:10.3329/pa.v21i1-2.16766

Curry GN, Koczberski G, Lummani J, Nailina R, Peter E, McNally G, Kuaimba O (2015) A bridge too far? The influence of socio-cultural values on the adaptation responses of smallholders to a devastating pest outbreak in cocoa. Glob Environ Chang 35:1-11. doi:10.1016/j. gloenvcha.2015.07.012

Deressa TT, Hassan RM, Ringler C, Alemu T, Yesuf M (2009) Determinants of farmers' choice of adaptation methods to climate change in the Nile Basin of Ethiopia. Glob Environ Chang 19(2): 248-255. doi:10.1016/j.gloenvcha.2009.01.002

Faruque G, Sarwer RH, Karim M, Phillips M, Collis WJ, Belton B, Kassam L (2016) The evolution of aquatic agricultural systems in Southwest Bangladesh in response to salinity and other drivers of change. Int J Agric Sustain 1-23. doi:10.1080/14735903.2016. 1193424

Gehlich-Shillabeer M (2008) Poverty alleviation or poverty traps? Microcredits and vulnerability in Bangladesh. Disaster Prev Manag 17(3):396-409

General Economics Division (2015) Bangladesh Delta Plan 2100 formulation project. Dhaka: Planning Commission, Government of Bangladesh. http://www.bangladeshdeltaplan2100.org

Gifford R (2011) The dragons of inaction: psychological barriers that limit climate change mitigation and adaptation. Am Psychol 66(4): 290-302 http://dx.doi.org/10.1037/a0023566

Grothmann T, Patt A (2005) Adaptive capacity and human cognition: the process of individual adaptation to climate change. Glob Environ Chang 15(3):199-213. doi:10.1016/j.gloenvcha.2005.01.002

Haasnoot M, Kwakkel JH, Walker WE, ter Maat J (2013) Dynamic adaptive policy pathways: a method for crafting robust decisions for a deeply uncertain world. Glob Environ Chang 23(2):485-498. doi: 10.1016/j.gloenvcha.2012.12.006

Hasanuzzaman A, Rahman M, Islam S (2011) Practice and economics of freshwater prawn farming in seasonally saline rice field in Bangladesh. Mesopotamian J Mar Sci 26(1):69-78

Hatje V, de Souza MM, Ribeiro LF, Eça GF, Barros F (2016) Detection of environmental impacts of shrimp farming through multiple lines of evidence. Environ Pollut. doi:10.1016/j.envpol.2016.06.056

Herbeck LS, Unger D, Wu Y, Jennerjahn TC (2013) Effluent, nutrient and organic matter export from shrimp and fish ponds causing eutrophication in coastal and back-reef waters of NE Hainan, tropical China. Cont Shelf Res 57:92-104. doi:10.1016/j.csr.2012.05.006

Hossain MS, Dearing JA, Rahman M, Salehin M (2016) Recent changes in ecosystem services and human well-being in the Bangladesh coastal zone. Reg Environ Chang 16(2):429-443. doi:10.1007/ s10113-014-0748-Z

Huq N, Hugé J, Boon E, Gain AK (2015) Climate change impacts in agricultural communities in rural areas of coastal Bangladesh: a tale of many stories. Sustainability 7(7):8437-8460

Ingalls ML, Stedman RC (2016) The power problematic: exploring the uncertain terrains of political ecology and the resilience framework. Ecol Soc 21(1). doi:10.5751/ES-08124-210106

Islam MS (2008) In search of 'white gold': environmental and agrarian changes in rural Bangladesh. Soc Nat Resour 22(1):66-78. doi:10. 1080/08941920801942255

Islam SN, Gnauck A (2008) Mangrove wetland ecosystems in GangesBrahmaputra delta in Bangladesh. Front Earth Sci China 2(4):439 448. doi:10.1007/s11707-008-0049-2

Islam S, Kibria Z (2006) Unravelling KJDRP - ADB financed mass destruction in southwest coastal region of Bangladesh [online]. Satkhira: Uttaran. Available: http://www.internationalrivers.org/ files/attached-files/khulna_jessore.pdf [Accessed 20 Nov 2014]

Islam M, Sallu S, Hubacek K, Paavola J (2014) Limits and barriers to adaptation to climate variability and change in Bangladeshi coastal fishing communities. Mar Policy 43:208-216. doi:10.1016/j. marpol.2013.06.007

Joffre O, Prein M, Tung P, Saha S, Hao N, Alam M (2010) Evolution of shrimp aquaculture systems in the coastal zones of Bangladesh and Vietnam: a comparison. In: Hoanh CT, Szuster B, Kam S-P, Noble A, Ismail AM (eds) Tropical deltas and coastal zones: food production, communities and the environment at the land-water Interface. CABI Publishing, London

Johnson FA, Hutton CW, Hornby D, Lázár AN, Mukhopadhyay A (2016) Is shrimp farming a successful adaptation to salinity intrusion? A geospatial associative analysis of poverty in the populous Ganges- 
Brahmaputra-Meghna Delta of Bangladesh. Sustain Sci 11(3):423439. doi:10.1007/s11625-016-0356-6

Jones L, Boyd E (2011) Exploring social barriers to adaptation: insights from western Nepal. Glob Environ Chang 21(4):1262-1274. doi:10. 1016/j.gloenvcha.2011.06.002

Klein RJT, Midgley GF, Preston BL, Alam M, Berkhout FGH, Dow K, Shaw MR (2014) Chapter 16 - Adaptation opportunities, constraints, and limits. In: Field CB, Barros VR, Dokken DJ, Mach KJ, Mastrandrea MD, Bilir TE, Chatterjee M, Ebi KL, Estrada YO, Genova RC, Girma B, Kissel ES, Levy AN, MacCracken S, Mastrandrea PR, White LL (eds) Climate change 2014: impacts, adaptation, and vulnerability. Part A: global and sectoral aspects. Contribution of Working Group II to the fifth assessment report of the Intergovernmental Panel of Climate Change. Cambridge University Press, Cambridge

Kori N (1996) The impact of shrimp cultivation on soils and environment in Paikgacha region, Khulna (limited to polders 20,21,22,23 and 29). Nijera Kori, Dhaka

Manju TH (1996) Political economy of shrimp culture in Bangladesh. Grameen Trust, Grameen Bank, Dhaka

Mersha AA, Van Laerhoven F (2016) A gender approach to understanding the differentiated impact of barriers to adaptation: responses to climate change in rural Ethiopia. Reg Environ Chang, 1-13. doi:10. 1007/s10113-015-0921-z

MOFL (2014) National Shrimp Policy 2014 [in Bangla]. Ministry of Fisheries and Livestock, Government of People's Republic of Bangladesh, Dhaka

Nuruzzaman M (2006) Dynamics and diversity of shrimp farming in Bangladesh: technical aspects. In: Atiq R, Quddus AHG, Pokrant B, Ali ML (eds) Shrimp farming and industry: Sustainability, trade and livelihoods. University Press Ltd. and Bangladesh Centre for Advanced Studies (BCAS), Dhaka

Nuruzzaman M, Anwari B, Shahjahan M, Maniruzzaman (2001) The dynamics and diversity of the shrimp farming in Bangladesh [online]. Department of Fisheries. Available: www.shrimpfoundation. org [Accessed 20 Nov 2014]

Orchard SE, Stringer LC, Quinn CH (2016) Mangrove system dynamics in Southeast Asia: linking livelihoods and ecosystem services in Vietnam. Reg Environ Chang 16(3):865-879. doi:10.1007/ s10113-015-0802-5

Osbahr H, Twyman C, Adger WN, Thomas DS (2010) Evaluating successful livelihood adaptation to climate variability and change in southern Africa. Ecol Soc 15(2):27 http://www.ecologyandsociety. org/vol15/iss2/art27/
Paprocki K, Cons J (2014) Life in a shrimp zone: aqua- and other cultures of Bangladesh's coastal landscape. J Peasant Stud 41(6):1109-1130. doi: $10.1080 / 03066150.2014 .937709$

Paul BG, Vogl CR (2011) Impacts of shrimp farming in Bangladesh: challenges and alternatives. Ocean Coast Manag 54(3):201-211. doi:10.1016/j.ocecoaman.2010.12.001

Pokrant B (2014) Brackish water shrimp farming and the growth of aquatic monocultures in coastal Bangladesh. In: Christensen J, Tull M (eds) Historical Perspectives of Fisheries Exploitation in the Indo-Pacific. Springer, London

Pouliotte J, Smit B, Westerhoff L (2009) Adaptation and development: livelihoods and climate change in Subarnabad, Bangladesh. Clim Dev 1(1):31-46. doi:10.3763/cdev.2009.0001

Quinn CH, Ziervogel G, Taylor A, Takama T, Thomalla F (2011) Coping with multiple stresses in rural South Africa. Ecol Soc 16(3):2. doi: 10.5751/ES-04216-160302

Rahman M, Hossain M (2013) Production and export of shrimp of Bangladesh: problems and prospects. Progress Agric 20(1-2):163171

Sallu SM, Twyman C, Stringer LC (2010) Resilient or vulnerable livelihoods? Assessing livelihood dynamics and trajectories in rural Botswana. Ecol Soc 15(4):3 http://www.ecologyandsociety.org/ vol15/iss4/art3/

Shackleton S, Ziervogel G, Sallu S, Gill T, Tschakert P (2015) Why is socially-just climate change adaptation in sub-Saharan Africa so challenging? A review of barriers identified from empirical cases. Wiley Interdiscip Rev Clim Chang 6(3):321-344. doi:10.1002/wcc. 335

Snorek J, Renaud FG, Kloos J (2014) Divergent adaptation to climate variability: a case study of pastoral and agricultural societies in Niger. Glob Environ Chang 29:371-386. doi:10.1016/j.gloenvcha. 2014.06.014

Swapan MSH, Gavin M (2011) A desert in the delta: participatory assessment of changing livelihoods induced by commercial shrimp farming in Southwest Bangladesh. Ocean Coast Manag 54(1):45-54. doi:10.1016/j.ocecoaman.2010.10.011

Szabo S, Hossain MS, Adger WN, Matthews Z, Ahmed S, Lázár AN, Ahmad S (2016) Soil salinity, household wealth and food insecurity in tropical deltas: evidence from south-west coast of Bangladesh. Sustain Sci 11(3):411-421 http://dx.doi.org/0.1007/s11625-0150337-1

Wise R, Fazey I, Smith MS, Park S, Eakin HC, Van Garderen EA, Campbell B (2014) Reconceptualising adaptation to climate change as part of pathways of change and response. Glob Environ Chang 28:325-336. doi:10.1016/j.gloenvcha.2013.12.002 